izvor moralnosti pogoduje čovjekovoj poziciji. Čovjek, kao religiozno biće usmjereno na transcendentno, upućen je na Boga koji je izvor svega dobra. S obzirom na to postoje brojni prigovori, zbog čega se problematičnim nameće govor o kriterijima moralnosti. Za tematiku autoričina rada bitno je naglasiti odnos između morala i religije gdje: »moral podrazumijeva religiju« i »moral podržava religiju «.

Sljedeći rad, »Poglajnov kršćanski personalizam«, donosi pregled života i rada Stjepana Tomislava Poglajena i njegov doprinos razvoju kršćanskoga personalizma. Zahvaljujući svojem životnom putu, Poglajen razvija ideju kršćanskog personalizma koji se odražava u njegovu životu i djelovanju. Poglajen postaje anđeo Slovačke pod njemačkom okupacijom i uspijeva organizirati život slovačke Crkve i očuvati vjeru naroda usprkos progonima njemačkih vlasti. Još i prije, Poglajen se zalaže za promociju personalizma člancima objavljenima u časopisu Glasnik Srca Isusova i Mariji$n a$ te kao urednik časopisa Život. Najpoznatija mu je propovijed Kralju vjekova kojemu sve živi i spis Temeljni obrisi ljudskog poretka u kojima naglašava zauzetost za čovjeka i upozorava na vrijednost Osobe kao polazišne točke kršćanstva. Osoba je za Poglajena integrativna cjelina, središnja i izvorna stvarnost ljudskog društva, opće vrijedna, neposredna i normativna mjera svakog ljudskog poretka, želi li se da bude ljudski (usp. str. 298).

Rad Janeza Juhanta razvija tematiku istraživanja religije u suvremenom svijetu s naglaskom na nekoliko tema. Prvotno, govori se o simboličkom temelju religioznosti. Simboličnost je crta poveznica razlikovanja religije i kulture i osnovni oblik čovjekove komunikacije. Simbolima se opisuje i označava religiozno i transcendentno. Sa simbolom u temelju, problematika se nastavlja na odnos i problematiku religije i znanosti, od srednjega vijeka do današnjih dana. Od poimanja religije do izopačenosti religioznoga, autor daje prikaz transformacije doživljavanja osjećaja za religijsko koji se bori s moderno-tehnološkim shvaćanjem znanstvenosti. »Religio《 kao odnošaj prema svetinji s vremenom potpada pod monopol totalnih sistema i ideologija koje svetim smatraju profano. Zbog toga, rad nastoji ponuditi refleksiju na suvremene političko-vjersko-ideološke sukobe u čijim je temeljima shvaćanje religioznosti.

Posljednji u nizu članaka u zborniku jest članak Mile Babića »Religija u filozofiji Jürgena Habermasa«. Donosi pogled na Habermasovu intervenciju u problematiku odnosa prosvijećene spoznaje naprema religijskom iskustvu. »Jürgen Habermas nastoji prevladati tu isključivost tako što zahtjeva da i religija i prosvjetiteljstvo budu kritički prema samima sebi, da se podvrgnu sudu kritičke refleksije, odnosno da reflektiraju o svojim granicama.« (str. 329). Habermasova pozicija je ona intersubjektivnoga uma u kojemu pojedinačna spoznaja izlazi ususret subjektu i oslanja se na medij u kojemu su svi odgovorni za stvaranje slike svijeta. Upravo zato što su ljudi različiti, moraju jedni od drugih učiti jer se vjera i znanje ne mogu svesti jedno na drugo (str. 245). Habermasova pozicija pomiruje racionalan um i »religioznu« spoznaju.

Zbornik donosi radove različita sadržaja i time doprinos istraživanju izrazito zahtjevne problematike koja je sadržana u naslovu zbornika. Naravno, zbornik ne može obuhvatiti cijelu problematiku filozofije i teologije $u$ kontekstu znanstveno-tehničke civilizacije, no može doprinijeti rasvjetljavanju iste problematike i ukazati na potrebu proučavanja iste. Sabrani radovi svjedoče idejama i problemima s kojima se suočavaju filozofija i teologija. Te su ideje i problemi aktualni i o njima treba govoriti i pisati da bi se problematika riješila, a ideje ostvarile. U rukama čitatelja, koji traži odgovore na predstavljene teme, ovaj zbornik radova može poslužiti kao još jedna stepenica prema razumijevanu »filozofije i teologije u kontekstu znanstvenotehničke civilizacije $\ll$.

Filip Martin Svibovec

doi: $\underline{10.21464 / f i 38318}$

\section{Matjaž Potrč}

\section{Pojave i psihologija}

\section{Fenomenološki spisi}

Lara, Zagreb 2017., prevela Ksenija Premur

U siječnju 2017. okončan je tisak spisa čuvenog slovenskog filozofa, autora više od 240 radova, Matjaža Potrča, naslova Pojave i psihologija (fenomenološki spisi), objavljenog u nakladi izdavačke kuće Lara iz Zagreba. Djelo je originalno objavljeno sada već davne 1995. te smatram da je domaće čitateljstvo istinski privilegirano i počašćeno odlukom nakladnika Lara da ga prevede na hrvatski te ga učini dostupnim ovomjesnom čitateljstvu. Djelo je svojevrstan oštroumni analitički pre- 
gled fenomenološke filozofijske tradicije, od Brentana, preko Husserla, do Heideggera, uz njihovo konsteliranje s pregršt manje poznatih, ali u odnosu na fenomenološku predmetnost, iznimno bitnih autora, kao što su France Veber, James Gibson i ostali, uz naglašavanje krucijalnih metodoloških smjernica kojima se valja voditi prilikom adekvatno širokog misaonog razmatranja fenomenologije, kao što su, primjerice, mereologija, organska jedinstvenost ili affordances. Djelo je sadržajem iznimno bogato i opširno te adekvatna mereološka kvalitativna analiza sviju relevantnih dijelova jednostavno nije izvediva s obzirom na kartičnu ograničenost prikaza i zbog toga ću nastojati ukazati na najvažnije momente.

Potrč u uvodnom poglavlju, naslovljenom »Fenomenologija i kognitivna znanost«, navodi da njegov eros za izučavanjem fenomenologije traje već duže vrijeme, no čitajući slovenskog filozofa Francea Vebera otkriva nekoliko temeljnih srodnosti između fenomenologije i naturalizirane filozofije psihologije te smatra da korijene filozofije navedenog valja potražiti u samim temeljima fenomenologije i to u djelu Franza Brentana. O kauzalnom hodu spisa Potrč piše:

»Ponajprije ću se obazreti na fenomenologiju, a potom i na kognitivnu znanost. Pregled će biti uspoređen i obojen mojim osobnim iskustvom. Na kraju ću izričito izložiti nekoliko vlastitih teza koje sam zagovarao. Koristit ću ih zato da bih ustanovio možemo li fenomenologiju i kognitivnu znanost uopće dovesti u vezu, te možda i bi li nam pritom uzmogle biti na pomoći i ove moje teze.« (str. 8)

Potrč fenomenologiju definicijski određuje kao nauk o pojavama, kao vrstu filozofije koja se bavi fenomenima (odnosno pojavama) koji mogu biti fizikalni i psihološki. Pritom, uvodi Brentana kao primjer začetnika refleksije o intencionalnosti (čije će stavove elaborirati tijekom čitavog spisa te koji zauzima ulogu centralnog protagonista među reflektiranim misliocima: »Brentana čitam na način da je upravo on zasnovao nauk o pojavama, odnosno fenomenologiju, i to kada je u modernu filozofsku raspravu iznova uveo pojam intencionalnosti«/str. 9/), izvodeći njegovo stajalište o razmjeru intencionalnog u-postojanja (in-eksistence), kako ga je Brentano odredio u svojem djelu Psihologija s empirijskog gledišta. Potrč navodi:

»Propozicijske usmjerenosti jedan su primjer intencionalnih pojava. Bilo kako bilo, u svakom slučaju možemo ustvrditi da je intencionalnost ona posebna karakteristika pojava koje pripadaju nauku o pojavama. Nauk o pojavama, odnosno fenomenologija stoga proučava pojave kao intencionalna bivstva.« (str. 10)

Također, naglašava da je propozicijska usmjerenost jedan od načina izlaganja intencional- nih pojava, ali intencionalne pojave omogućuju još jednu vrstu objašnjenja, a riječ je o objašnjenju u izrazima dijelova i cjelina.

»Objašnjenje uz pomoć dijelova i cjelina mereološko je i ontološko. U tom je smislu postavljeno nasuprot prethodnom isticanju jezikoslovnih podataka, iako su ti jezikoslovni podaci izraženi uz pomoć psiholoških podataka, kakve možemo pronaći u našem primjeru propozicijske usmjerenosti.« (str. 11)

Mereologija je možda i ključna metoda koju Potrč koristi kao adekvatnu analitičku fenomenološku tehniku te ukazuje na činjenicu da je organska jedinstvenost centralna propozicija za nauk o pojavama, a samu pojavu definira kao akcidentalnu cjelinu koja ima supstanciju za vlastiti dio. Načelo da akcidentalna cjelina ima supstanciju kao svoj vlastiti dio Potrč naziva Chisholmovo načelo jedinstvenosti jer takvo stajalište zauzima i filozof Chisholm kojeg vrlo cijeni. Nakon CPU-a, Potrč iznosi misao o ekologiziranoj organskoj jedinstvenosti, pritom imajući na umu eksternalističko stajalište pri kojem je prigodom razlučivanja temeljan vanjski svijet te koje tvrdi da organizam ne smijemo proučavati odijeljeno od njegove okoline. Osim psihologa Gibsona, reprezentativnim predstavnikom ekologizma Potrč smatra i Husserla i Heideggera, pri čemu navodi da Fodor i Dreyfus smatraju da je Husserl zagovornik internalizma.

Nadalje, Potrčevu znatiželju pobuđuje i pitanje kognitivne znanosti, što razrješava mišlju da je ona u principu naturalizirana spoznajna teorija, nasuprot čistoj kogniciji. Po pitanju definicije kognitivne filozofije Potrč piše:

»Kognitivna filozofija je vrsta naturalističke spoznajne teorije koja se bavi raznim pojavama, tako da sučeljava pitanja u novom znanstvenom ruhu s njihovim časnim precima, kakav je problem odnosa između duše i tijela, uključujući pitanja kvalitativnih osjeta ili kvalija i svijesti. Činjenica je da je znanstvena zajednica u više prigoda priznavala filozofima kao njihov značajan doprinos upravo suočavanje novijeg tehničkog razvoja u istraživanjima spoznajnih sposobnosti tradicionalnim filozofskim zagonetkama.« (str. 18)

$\mathrm{Na}$ to, piše o percipiranju kao modelu, koristeći Marrov model koji razlikuje nekoliko razina proučavanja spoznajnih sustava: analizu apstraktnih problema, formalni postupak i razinu fizikalne izvedbe. Dotični je model služio kao opća shema zornog prikazivanja različitih spoznajnih funkcija te za njihove računalne izvedbe, a općenito uzevši, uz pomoć takvih modela dokazano je da je percipiranje u velikoj mjeri zamršena pojava, koja se zbiva na više razina te je u skladu s modularnim načelima primijenjena na mnogim područjima, kakvo je, primjerice, čitanje. Metodom proučavanja takvih perceptivnih procesa i posebice uz razvoj računala iznova je postav- 
ljeno i pitanje o strukturi duha. Potrč naglašava da je najznačajnije unapređenje, koje svoje posljedice ima i za modeliranje duha, nadošlo promjenom strukture samih računala, pritom misleći na pomak od simbolnih računalnih modela duha prema konekcionističkim modelima duha. Posredstvom navedenih razmišljanja dolazi do točke na kojoj će, smatra, biti korisno razlikovati u temelju dvije razine spoznavanja, odnosno kognicije, višu i nižu.

U nastavku djela, Potrč združuje fenomenologiju i kognitivnu znanost, spajajući ih pri tangenti spoznajne teorije te navodeći da je ona središnja i za fenomenologiju (filozofiju) i za kognitivnu znanost. Pritom postavlja tezu da je kognitivna znanost modeliranje čovjekove kognitivne (spoznajne) strukture, a ako je kognitivna znanost modeliranje čovjekove spoznajne strukture, tada je bitno pozivanje na fenomenologiju.

»... tome je tako jer se fenomenologija bavi čovjekovom spoznajnom, odnosno kognitivnom strukturom, i to sve od osjeta i percipiranja do viših, pojmovnih zadataka zaključivanja koje izvode ljudska bića, uključujući činjenicu da su bića članovi zajednice.« (str. 25)

Potrč napominje da je teza internalizma često združiva s Husserlovim djelom, unatoč tome što je u razdoblju njegova Lebenswelt pristupa naizgled u većoj mjeri eksternaliziran, pa čak i wittgensteinovski, dok je, s druge strane, Husserlov učenik Heidegger u vlastitoj fenomenologiji podjednako tako u većoj mjeri ekesternaliziran i ekološki orijentiran.

Nadalje, autor uvodi nekoliko teza koje je razvijao posljednjih nekoliko godina prije objavljivanja djela, a teze su: a) značaj kognitivnih mehanizama na razini osjeta u tumačenju individuacije; b) teorije o Dvije razine koja se odnosi na činjenicu da su mehanizmi individuacije na razini osjeta te na višoj spoznajnoj razini slični, iako nisu identični (na taj način, tvrdi, izbjegavamo i kružnost); c) nužnost proučavanja pojmovne prototipske strukture (uz pomoć pristupa kakav je, primjerice, koherentizam); i d) sadržaj kao u temelju pojmovni i prototipski (prirodu valja lučiti ondje gdje već postoje prirodni pregibi). Temeljno pitanje koje se u Potrčevu umu koprca nakon uvođenja navedenih teza jest »kako povezati fenomenologiju i kognitivnu znanost«, a odgovor nalazi u organskoj jedinstvenosti kao modelu (CPU - Central Processing Unit) te tvrdi da da je svijest, kojom se fenomenologija bavi u temelju, ništa drugo doli čovjekova središnja jedinica za obradu podataka (dakle, CPU).

Kroz naredno poglavlje, naslova »Analitička filozofija i fenomenologija«, autor u teleološku sintezu dovodi naslovne dvije discipline, smatrajući da je jedino ispravno razumijevanje fenomenologije moguće samo na analitičkom temelju, a piše i sljedeće:

»Štoviše, fenomenologija (kao i većina drugih značajnih filozofija u današnje vrijeme i u povijesti) vrsta je analitičke filozofije. Samo je zaborav izvornog značenja pojma fenomen ili pojava u nekim suvremenim fenomenologijama omogućio u cijelosti neopravdano lučenje fenomenologije od analitičke filozofije.« (str. 33)

Dodao bih da valja biti oprezan prilikom sintetiziranja fenomenologije i analitike, kao i s ortodoksnim provođenjem analitičkih postulata bez da se u obzir uzima teleološku nužnost kretanja analitike $\mathrm{k}$ sintezi jer $\mathrm{u}$ suprotnom analitičar postaje solipsist zarobljen u kuli čvrsto utvrđenih pravila, zarobljenik »umjetnog totaliteta kauzaliteta «.

Nadalje, Potrč piše o razgovoru sa slovenskim filozofom/fenomenologom Tinom Hribarom koji tvrdi da su pojave, odnosno fenomeni, kako ih sam naziva, idealni, što znači da nisu empirijski, no Potrč osporava takav ethos ukazujući na razlikovanje pojava:

»Vidim samo jednu mogućnost, a to je da protumačimo kako se pojave razlikuju. I to ćemo učiniti tako da navedemo kako su pojavi knjiga potpora konkretne knjige, te da su pojavi mačka potpora empirijske dlakave mačke. Ako Hribar raspolaže kakvim boljim tumačenjem o tome na osnovu čega se pojava knjige i mačke razlikuju, bilo bi pošteno da ga objelodani.« (str. 35)

Također, Potrč kritizira Hribarov stav o Husserlu kao začetniku fenomenologije, navodeći da je Brentano zapodjenuo raspravu o fenomenima ili pojavama, dok ju je Husserl samo preuzeo te raspravio na svoj način. Husserlovu metodu stavljanja u zagrade Potrč smatra posve neutemeljenom s obzirom na to da ona briše potvrdnu i obvezujuću moć iskaza te tako možemo izreći bilo što, a da se pritom ničemu ne obvezujemo. Međutim, naglašava da s prosudbom Husserla valja biti oprezan iz razloga što u njegovu radu postoje barem četiri različite epohe, od naturalizma preko antinaturalizma i antipsihologizma, do idealizma i transcendentalizma. Nadalje, autor mnije o analitičkoj filozofiji, o kojoj piše:

»Analitička filozofija nije neki posebni smjer ili struka, kakvi su, primjerice, fenomenologije i iznova ontologija. Analitička filozofija je ponajprije metoda koju možemo koristiti u fenomenologiji, spoznajnoj teoriji, u ontologiji ili drugdje. Glavna je djelatnost analitičke filozofije, kako to kazuje već sam njezin naziva, analiza. $U$ tom smislu imamo posla s analizom pojmova te argumenata na nekom području. Tom klasičnom razumijevanju analitičke filozofije želio bih dodati da je adekvatna analitička filozofija zapravo naturalistička i to u tom smislu da se zanima za znanost ili, pak, da svoje pojmovne rezultate istraživanja potkrijepi korištenjem rezultata znanosti.« (str. 40) 
Linijom navedene argumentacije, pod analitičke filozofe smješta Aristotela, Tomu Akvinskog, Descartesa, Kanta i Brentana.

Poglavlje o fenomenologiji i analitičkoj filozofiji Potrč okončava mišlju da nam ispravno razumijevanje fenomena, odnosno pojava, predočuje analitičku filozofiju kao jedinu koja nam može pojasniti nauk o pojavama ili fenomenologiju.

U narednom poglavlju autor zapodijeva refleksiju o naturaliziranoj i eksternaliziranoj brentanovskoj ontologiji i to kroz dva tematska odsječka. U prvom iznosi nekoliko temeljnih činjenica o ontologiji (posebice u vezi s brentanovskom ontologijom supstancije i akcidencije), a u drugom dijelu ocrtava ontološku tezu o organizmima kao o jedinim pravim bivstvima:

»Tezu o tome da stolice i kamenje ne postoje možemo braniti uz pomoć tvrdnje da nemaju vlastitih dijelova. Stolica nije ništa drugo doli skup: nema nikakve nužnosti da bi njezina noga, taj poseban komad drveta, postojala u njegovoj strukturi; podjednako tako, mogli bismo je zamijeniti nekim drugim komadom drveta. Slično vrijedi i za kamenje. U primjeru organizama, međutim, njihovi dijelovi pokazuju jedinstvenost, koja nam dopušta da ih nazivamo bivstvima. Partikularije, od kojih je sačinjeno moje tijelo, svedene su zajedno s nekom vrstom nužnosti, koju ne možemo pronaći u primjeru proizvoda i neživih stvari. Činjenica je, dakako, da su upravo te partikularije, koje su tvorile moje tijelo kada sam imao dvije godine, sada vjerojatno u cijelosti zamijenjene drugim pojedinačnim stanicama materije (možda s izuzetkom nekih dijelova mojeg mozga). I budući da sam previše debeo, sve moje partikularije ni na koji način ne mogu biti funkcionalne. Pa ipak, struktura dijelova u mojem organskom tijelu posjeduje izvjesnu vrstu teleološke nužnosti jer je pridružena zajedno. U tom bi smislu samo sastavni dijelovi organskih tijela bili vlastiti dijelovi bivstva koje tvore: jer ih zajedno održava zajedničko načelo, koje vodi strukturu organskog svijeta, načelo teleologičnosti.« (str. 66)

Jedna od temeljnih teza poglavlja zastupa misao da je svijest organska cjelina te da mjerilo organske jedinstvenosti mjerilo uz čiju pomoć određujemo bivstva ili čak postojanje bivstva, a s obzirom na to mjerilo, smatra Potrč, organizmi su jedina bivstva - dok svijest predstavlja najvišu razinu organske jedinstvenosti u navedenoj konstelaciji, subjekt predstavlja sjedinjujuće načelo svijesti.

U poglavlju »Fenomenologija ili nauk o pojavama«, naglasak je na organskoj jedinstvenosti te na tezi o ograničenju bivstava. $\mathrm{Pa}$ tako, Potrč razvrstava dijelove pojava glede njihove rastuće ovisnosti o pojavama kao cjelinama, a potom uvodi misao o osobi kao nositelju misli, a samu misao percipira kao cjelinu. Citiram:

»Razmotrimo na ovom mjestu mogućnost da je misao cjelina i da sam ja dio te cjeline. Prvim se tu- mačenjem tvrdi da misao o mački promatramo kao neovisno bivstvo u kojem udjela može imati veći broj osoba. To bi predstavljalo mogućnost misli, a da je pritom netko ne bi podupirao (unatoč tome da mogućnost misli, koje s drugima ne dijelimo, još ne znači da nisu moguće misli koje s drugima dijelimo). Pa ipak, misao kojoj nitko ne bi bio oslonac, ne bi bila u svijetu i stoga ne bi bila pojava, odnosno fenomen.« (str. 77)

Nadalje, Potrč promatra i pojave kao cjeline, a kroz nišu sublimacije promatrača i pojave, te iznosi temeljnu Brentanovu skicu pojave, odnosno fenomena, kroz koju je supstancija prikazana kao dio akcidencije kao cjeline, a čime Potrč želi istaknuti dominaciju predikativne kategorije u odnosu na predmetnopojavnu. Naglašava i suprotnost takvog gledišta s aristotelijanskim pogledima na odnos između supstancije i akcidencije, pri kojem je akcidencija za Aristotela nešto dodano supstanciji koja bez akcidencija bez poteškoća i nadalje postoji. Stoga, tvrdi Potrč, u Aristotela ne može biti govora o fenomenologiji. Također, u pasusu se dotiče i značaja reizma u odnosu na ispravno predočavanje pojava, odnosno fenomena, te piše o Brentanovoj podjeli na jake i slabe cjeline, pri čemu su slabe cjeline u blizini skupova, odnosno agregata (primjerice stado ovaca), dok bi jake cjeline bile bliskije organskoj jedinstvenosti (živa ovca koja je sačinjena od svojih dijelova). Potrč kroz poglavlje brani Brentanovu misao da su pojave, odnosno fenomeni, jedina postojeća bivstva, pri čemu je trodiobno razvrstao bivstva na: uobičajene stvari (dijeli ih na predmete $u$ najširem smislu te na izratke), organizme i pojave. Rapravu okončava sljedećim:

»Najprimjerenije je vjerojatno ako na fenomenologiju gledamo kao na characteristica universalis, kao na razumijevanje o tome kako izgraditi opću vrstu gramatike pojmova, odnosno fenomena. Ta je gramatika napisana na temelju mereoloških načela. Pojave, odnosno fenomene mereoloških načela predstavljaju upravo kao akcidentalne cjeline koje maju supstanciju kao svoje vlastite dijelove. Mereološka načela zapravo predstavljaju gramatiku (dopuštene crte) združivanja i zajedničkog nastupanja pojava, odnosno fenomena, tako da imaju supstanciju za svoj dio.« (str. 108)

Upravo pri citiranim mišljevinama, primjećujem holonističku međuprostornu relevanciju mereološke metodologije, koja predstavlja svojevrsnu paradigmu sunosite ekscentrične pozicionalnosti same fenomenologije, odnosno bitak percipirajućeg modelnog telosa mereologije, u odnosu na svijest.

U dodatku poglavlja, Potrč navodi da je, prema Brentanu, načelo organske jedinstvenosti ograničeno na područje psihološkog te nas, nadalje, vodi ka gibsonovskoj slici fenomena, odnosno pojava kao afordansa. Afordans 
(iz engl. affordance, prema: to afford) izraz je psihologa J. J. Gibsona za karakteristiku stvari da se organizmu za nešto pružaju: tako se stolica pruža meni kao čovjeku za sjedenje, a mravima za penjanje. Afordanse su smisaono bliske Heideggerovoj priručnosti, a sama nauka koju Gibson razvija naziva se psihološki ekologizam koji je, prema Potrču, na prvi pogled udaljen od fenomenologije, no teleološki ga je ipak moguće sublimirati.

Kroz iduće poglavlje naslova »Nauk o pojavama (fenomenologija), organska jedinstvenost i eksternalizirani Husserl« Potrč tumači organsku jedinstvenost i njezin značaj za fenomenologiju, a misaoni fokus je na Husserlu. Potrč tvrdi:

»Husserlov razvoj započinje s njegovim ranim naturalizmom, kada je brentanovske mereološke nazore upotrijebio na području brojeva. Na osnovi vlastitih nerazumijevanja stvarne moći takvog stajališta, Husserl je postepeno izgradio nauk o pojavama (fenomenologiju). To ga je dovelo do uvođenja drugačije inačice organske jedinstvenosti, što je doseglo svoj vrhunac u neposredno ekološkim eksternaliziranim stajalištima. Pa ipak, taj razvoj možemo jasno sagledati samo u slučaju ako se ogradimo od Husserlovog transcendentalizma i njegovih redukcija. Takav je postupak u cjelini opravdan jer sam Husserl nije izložio nikakvo opravdanje za uvođenje svojih fenomenoloških stajališta i s njima povezanih prethodnih redukcija.« (str. 123)

Kroz čitavo je djelo pristutan odbojan Potrčev etos spram Husserla, na granici nesnošljivosti, mahom usmjeren $\mathrm{k}$ deficitu organske jedinstvenosti u Husserlovoj fenomenologiji. Autor smatra da Husserlov filozofski znanstveni program nema nikakve mogućnosti da bi ikada mogao biti izvršen jer počiva na pogrešnim pretpostavkama, kakva su uvjerenja o adekvatnosti transcendentalizma i izvjesnom fenomenološkom redukcionizmu, te na taj način, smatra Potrč, nauk o pojavama (fenomenologija) zapravo nije ni program. Navodi i da je Husserlova prekretnica iz naturalističkog (empirijskog) u transcendentalno (apriorističko) gledište nastupila u knjizi Ideje, koju mnogi smatraju Husserlovim središnjim djelom, a što ga je dovelo u stajalište solipsističkog idealizma (na koji je Potrč, blago rečeno, alergičan). Osim Ideja, Potrč intenzivno analizira i Husserlova djela Stvar $i$ prostor te Logička istraživanja, pritom zaključujući da je u spisu Stvar i prostor podvrgnuo kritici pojednostavljeni subjektnoobjektni model percipiranja da bi ga polako zamijenio punokrvnim ekološkim. Citiram:

»Započeo je s jednostavnim modelima, te utirao put prema adekvatnijem razumijevanju stvari u realnoj perceptivnoj situaciji. Ukoliko i je riječ o mogućnosti solipsističkog tumačenja tog postupka, nije ga potrebno samo svesti na zahtjeve fenomenološke redukcije, već bismo mogli pokazati da na ovom mjestu iznova imamo određeno podudaranje s ekologizmom.« (str. 178)

Nadalje, fokus rasprave s Husserla prebacuje na Heideggera, za kojeg tvrdi da je sve što je učinio u Bitku i vremenu bilo samo preuzimanje izloženih nazora svojeg učitelja Husserla te njihovo daljnje razvijanje. Što se tiče stajališta organske jedinstvenosti, Heidegger započinje s cjelinom, sa svijetom, iako taj svijet nije postavljen nasuprot organizmu jer Heideggera zanima upravo bitak-u-svijetu, a ne svijet kao takav. Temeljno naučavanje intencionalnosti, koje nudi Heidegger, u izrazima je priručnosti (Zuhandenheit). Oruđe koristimo u svijetu te je ono model svrstavanja značenja u svijetu i njegovog preoblikovanja, no ipak, oruđe uvijek koristi netko, neki organizam, Dasein. Za Heideggera je cjelina svijet, iako je ta cjelina akcidentalna, utoliko ukoliko je to svijet organizma. Organska jedinstvenost je bila predočena kao krug, koji u svom središtu ima organizam, Dasein, kao supstanciju, kao svoj vlastiti dio. Dasein je ukotvljen u krug teleološke djelatnosti, a ta teleološka, svrhovita djelatnost smještena je u racionalnost i priznanje drugih (zabijanjem čekića u radionici kao stolar). Tako je Dasein ubačen u svijet, premda još uvijek postoji kao supstancija svijeta, vlastiti dio svijeta. Ono što je u Brentana započelo kao opis atomarnih pojava (fenomena) u kojima je svaka pojava imala supstanciju kao svoj dio, završava sa svijetom kao holističkim, cjelokupnim pojavama koje zadobivaju svoj smisao od organizma, od Daseina, kao od svojeg dijela, što Heideggera nedvojbeno čini ekologistom, a naredno poglavlje djela nosi naslov »Heidegger i ekologizam«, kroz koji Potrč nastoji barem do neke mjere pojasniti Heideggerov pojam intencionalnosti koji je, smatra, prilično rijetko jasno razložen. Potrč tvrdi da glavna uloga u objašnjenju duševnih stanja mora pripasti vanjskom svijetu i to posebice predmetima koji u njemu postoje, a problem intencionalnosti razlaže pitanjem: kako u svojim mislima mogu biti usmjeren na stolicu i kako ona ne može na isti način biti usmjerena na mena? No, mnije, na to pitanje još nema jedinstvenog odgovora te naglašava da filozofi i nadalje mogu graditi teorije o intencionalnosti. Nadalje, zanima ga eksternalizirani pojam intencionalnosti, a pod eksternalizmom ima na umu nauk o tome da duševna stanja možemo obuhvatiti uz pomoć vanjskih predmeta i događaja koje možemo naći izvan organizma koji raspolaže sadržajem. Piše:

»Kada imam sadržaj da je mačka na sagu, u određenju sadržaja temeljan je položaj mačke na sagu u vanjskom svijetu. I u primjeru kada predočavam mačku, za to su odgovorni susreti s mačkama u 
svijetu. Tako se čini da moram koristiti vanjske položaje kako bih obuhvatio sadržaje duševnih stanja.« (str. 188)

Eksternalizam suočava s njemu suprotnim polom - internalizmom - a jezgra internalizma leži u tvrdnji o tome da se obuhvaćanje duševnih stanja odvija samo uz pomoć onoga što je unutarnje organizmu koji na raspolaganju imas sadržajna duševna stanja, a što vodi k metodološkom solipsizmu, pri čemu svoje zanimanje moramo ograničiti na ono što je organizmu unutarnje. Predstavnika navedenog zrenja Potrč vidi u Husserlu, koji u Idejama tvrdi kako u zagrade moramo postaviti za svijet vezane tvrdnje te da ih moramo promatrati kao sadržaje unutarnje svijesti, a Heideggerov pomak prema eksternalizmu, dakle prema napuštanju učiteljeva stajališta, Potrč promatra u konstataciji da u određivanju svoje fillozofije učenici moraju tražiti druge puteve od učitelja. Kroz poglavlje, ključna predmetna mjesta zauzimaju i pitanja grubog $\mathrm{i}$ istančanog eksternalizma, ekološke psihologije (Gibsonov istraživački program) i biti-usvijetu, o čemu piše:

»Bit-u-svijetu adekvatna je za raspravu o naše obje točke. Prvo, ako je organizam (Dasein) ubačen u svijet, to znači da ne možemo ustrajavati na strogom lučenju između svijeta i organizma. Takvo je lučenje zapravo moguće samo iz kartezijanskog zornog kuta. U tom primjeru svijet možemo odrediti neovisno o organizmu, te između obojih postoji neka vrsta crte razgraničenja. Ako je organizam (Dasein) ubačen (geworfen) u svijet, ne može postojati nikakva razdvajanja.« (str. 194)

Potrč smatra da nakon navedenog nema nadalje potrebe govoriti o unutarnjim duševnim stanjima organizma te nam nisu potrebni spoznajni posrednici koji bi organizmu omogućili odgovarajuću osnovu za uvođenje istančane vrste eksternalizma, a do kraja djela elaboracijskim diskursom dominiraju Husserl i Heidegger. Najprije se osvrće na preokret tradicionalnog pitanja o bitku te na tradicionalni pristup spoznaji shvaćenoj kao odnos između subjekta i objekta, a na taj način uvodi raspravu o Heideggerovoj intencionalnosti, čime okončava svoj nepredvidljivi i intrigantni spis koji čitatelja nagoni na intenzivno izučavanje fenomenologije i promišljanje o sintetiziranju analitičke i kontinentalne fillozofske tradicije.

\section{Luka Janeš}

doi: $\underline{10.21464 / \mathrm{fi} 38319}$

\section{Srećko Horvat, Igor Štiks (ur.)}

\section{Dobro došli u pustinju postsocijalizma}

\section{Fraktura, Zaprešić 2015., preveo Davor Biličić}

Nedugo nakon izdanja na engleskom jeziku, objavljenog kod najuglednijeg svjetskog izdavača socijalističke literature, londonskonjujorške kuće Verso, objavljeno je i hrvatsko izdanje zbornika koji u originalu nosi naziv Welcome to the Desert of Post-socialism, uredničkog dvojca Srećko Horvat i Igor Štiks. Ovom dvojcu to nije prva zajednička knjiga jer su, također kod zaprešićke Frakture 2010. godine, objavili monografiju Pravo na pobunu. Uvod u anatomiju građanskog otpora.

Zbornik Dobro došli u pustinju postsocijalizma sastoji se od četiriju sadržajnih cjelina Prva nosi naslov »Od samoupravljanja do kapitalizma katastrofe«, a sadrži poglavlja koja su napisali Vladimir Unkovski-Korica, Andreja Živković i Marko Grdešić. Druga cjelina naslovljena je »Imaginarni postsocijalistički Balkan« te sadrži tekstove koje su napisali Maria Todorova, Tanja Petrović i Boris Buden. Zatim slijedi cjelina »Dva desetljeća nakon Jugoslavije: gorki plodovi tranzicije« koja uključuje doprinose Andreja Nikolaidisa, Agona Hamze i Mitje Velikonje. Naposljetku, u cjelinu »K Balkanskom proljeću? Novi politički subjekti« uvršteni su tekstovi Michaela G. Krafta, Jane Baćević i Ankice Čakardić. Četirima navedenim cjelinama prethode urednički predgovor hrvatskom izdanju naslovljen »Ljevica danas - pokreti, plenumi, partije « te urednički uvod, kao i u engleskom izvorniku, objavljen pod naslovom »Pobuna u pustinji tranzicije«. Na kraju knjige nalaze se bilješka sa zahvalama, bilješke o autoricama i autorima te kazalo imena.

Zbornik koji su priredili Horvat i Štiks treba gledati u širem kontekstu zbornikâ objavljenih s namjerom da se objasne procesi i posljedice postsocijalističke tranzicije u regiji Jugoistočne Europe. Naime, nakon ponovnog uvođenja kapitalističkih proizvodnih odnosa (Markovićev Zakon o poduzećima 1989. godine), sloma socijalizma i raspada socijalističke Jugoslavije, prestala je i proizvodnja znanja iz lijeve perspektive. Hegemoniju je preuzela, pogledamo li slučaj Hrvatske, nacionalistička teleologija epitomizirana u stavu da je hrvatski narod nakon tisućljeća tuđinske vlasti najzad dosanjao svoju državu. Glavnu 